\section{Early Eocene Cantius torresi- oldest primate of modern aspect from North America}

\author{
Philip D. Gingerich
}

Museum of Paleontology, University of Michigan, Ann Arbor, Michigan 48109, USA

The oldest primates of modern aspect (primates of prosimian tarsiiform-lemuriform or higher grade) are known from Lower Eocene strata of Sparnacian age in Europe ${ }^{1,2}$, Bumbanian age in $\mathbf{A s i a}^{3,4}$, and Wasatchian age in North America ${ }^{5}$. These first appearances coincide on all three northern continents with initial records of Artiodactyla, Perissodactyla and other modern mammalian

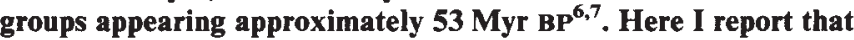
a newly discovered basal Wasatchian faunal assemblage older than any known previously includes the well-preserved dental remains of a new species of Cantius, the earliest representative of Eocene Adapidae and the oldest evidence of primates of modern aspect known from North America. This new Cantius is possibly ancestral to all later adapids, including the European Donrussellia and North American Pelycodus. Cantius torresi has premolars reminiscent of those in Omomyidae, suggesting that earlier lemuriform and tarsiiform primates were closely related and little differentiated at the beginning of the Eocene.

Two major groups of primates of modern aspect, tarsiiform Omomyidae and lemuriform Adapidae, are represented in the early Eocene of Europe ${ }^{8-12}$, Asia ${ }^{3,4,13}$ and North America ${ }^{14-20}$. Both groups appeared suddenly on northern continents during an interval of climatic warming ${ }^{21}$. No plausible ancestors of the two groups are present in known European, Asian or North American faunas of late Palaeocene age, suggesting their immigration from equatorial areas. The oldest North American omomyid, Teilhardina americana, is similar to the European Teilhardina belgica ${ }^{15,19}$. The oldest North American adapid known previously, Cantius ralstoni, is likewise similar to the European Cantius eppsi ${ }^{17,18}$. The discovery of a new North American Cantius demonstrably older than C. ralstoni is important in clarifying the dental morphology of primitive Adapidae.

\section{Cantius torresi n. sp.}

Holotype. University of Michigan [UM] 83470, left dentary with $\mathrm{P}_{3}-\mathrm{M}_{1}$ collected by Victor Torres from locality SC-67 in the Willwood Formation at the south end of Polecat Bench, Park County, Wyoming.

Age and distribution. Earliest Wasatchian Land-Mammal Age (early Eocene) of the Clark's Fork Basin, Wyoming, western North America. This species is known from two adjacent localities (SC-67 and 69) in a restricted 10-m stratigraphic interval within the Clarkforkian-Wasatchian boundary sandstone of Kraus $^{22}$.

Referred specimens. Holotype; UM 83467, left dentary with $\mathbf{M}_{2}$; and $\mathrm{Um} 83475$, right maxilla with $\mathrm{M}^{1-3}$ from the type locality. Um 66143, right dentary with $\mathbf{M}_{2-3}$ from SC-69.

Diagnosis. Differs from $C$. ralstoni, $C$. eppsi and all other species of Cantius in being smaller, having relatively square upper molars, and having shorter, relatively broader lower premolars and molars. $P_{4}$ is distinctive in having a broad trigonid and talonid. The paracristid connecting the paraconid and protoconid on $\mathrm{P}_{4}$ forms a right-angle with the metacristid connecting the metaconid and protoconid.

Description. The holotype dentary (Fig. 1a) preserves matrixfilled alveoli for the lower canine, a single-rooted $P_{1}$ and a double-rooted $P_{2}$. The crown of $P_{3}$ is simple with a single central protoconid cusp, no accessory paraconid or metaconid, and little more than a trace of a talonid. $P_{3}$ is $2.4 \mathrm{~mm}$ long and

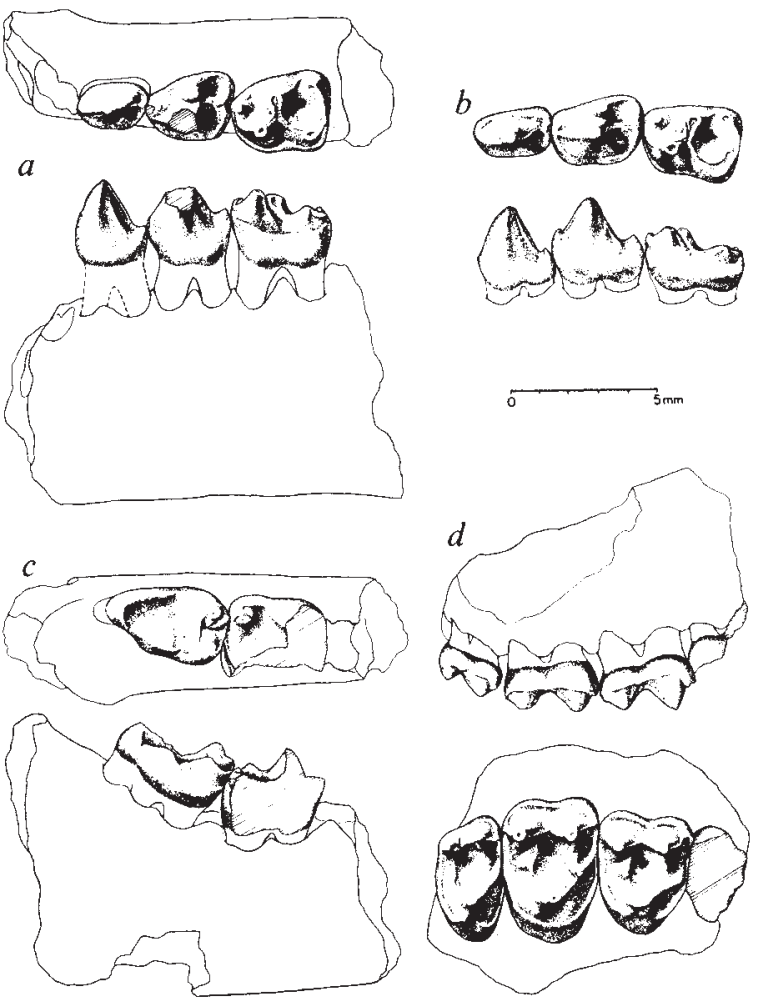

Fig. 1 Dentition of Cantius torresi, from the earliest Wasatchian of western North America, and Cantius eppsi, from the Sparnacian of UK. $a$, Left dentary of C. torresi [UM 83470, holotype] with $\mathbf{P}_{3}-\mathbf{M}_{1}$ in occlusal (top) and lateral (bottom) view. Partial alveoli for the single-rooted $P_{1}$ and double-rooted $P_{2}$ are shown in outline. The remains of the alveolus for the larger lower canine are obscured in these views. $b$, Right $P_{3}-M_{1}$ (reversed for comparison) of $C$. eppsi [Br. Mus. (Nat. Hist.) 15773, holotype] in occlusal and lateral view. $c$, Right dentary of $C$. torresi [UM 66143] with $\mathbf{M}_{2-3}$ in occlusal and lateral view. $d$, Right maxilla of $C$. torresi with $\mathrm{M}^{1-3}$ in lateral and occlusal view. Note the short Nannopithex fold of enamel running up the posterior surface of the protocone in occlusal view. This enamel fold does not join the postcingulum, and the earliest Cantius lacks a fully developed postprotocingulum.

$1.8 \mathrm{~mm}$ in maximum breadth. The crown of $\mathrm{P}_{4}$ is more complex, with a well-developed paraconid and metaconid in addition to the central protoconid. The metaconid is medial to the protoconid, making the trigonid unusually broad. The talonid on $\mathrm{P}_{4}$ is also broad, with a prominent central cristid obliqua and shallowly basined posteromedial corner. $\mathrm{P}_{4}$ is $2.8 \mathrm{~mm}$ long and $2.4 \mathrm{~mm}$ in maximum breadth. The crown of $\mathrm{M}_{1}$ is tritubercular with three distinct trigonid cusps and a broadly basined talonid. $\mathrm{M}_{1}$ is $3.3 \mathrm{~mm}$ long and $2.9 \mathrm{~mm}$ in maximum breadth. The crown of $\mathrm{M}_{2}$ is partially preserved in two specimens (UM 66143 and 83467 ), both are small, measuring $3.4 \times 3.2 \mathrm{~mm}$ and $3.2 \times 3.1 \mathrm{~mm}$ in length and width, respectively. The crown of $\mathbf{M}_{3}$ preserved in UM 66143 has a short trigonid, with paraconid and metaconid cusps closely appressed (Fig. $1 \mathrm{c}$ ). $\mathrm{M}_{3}$ is $4.3 \mathrm{~mm}$ long and $2.7 \mathrm{~mm}$ in maximum breadth. The talonid of $\mathbf{M}_{3}$ resembles that in other early Cantius species in having a very narrow hypoconulid lobe (1.5 mm broad).

Upper molars are preserved intact in one specimen (UM 83475; Fig. $1 d$ ). The crowns of both $\mathrm{M}^{1}$ and $\mathrm{M}^{2}$ are relatively square by comparison with later species of Cantius; both have prominent protocones, distinct paracones and metacones, and small but distinct paraconules and metaconules. There is a crest behind the protocrista representing a 'Nannopithex fold' or partially developed postprotocingulum as in other primitive adapids and omomyids. In later Adapidae this crest is either reduced and lost (Donrussellia, Protoadapis) or it is expanded 


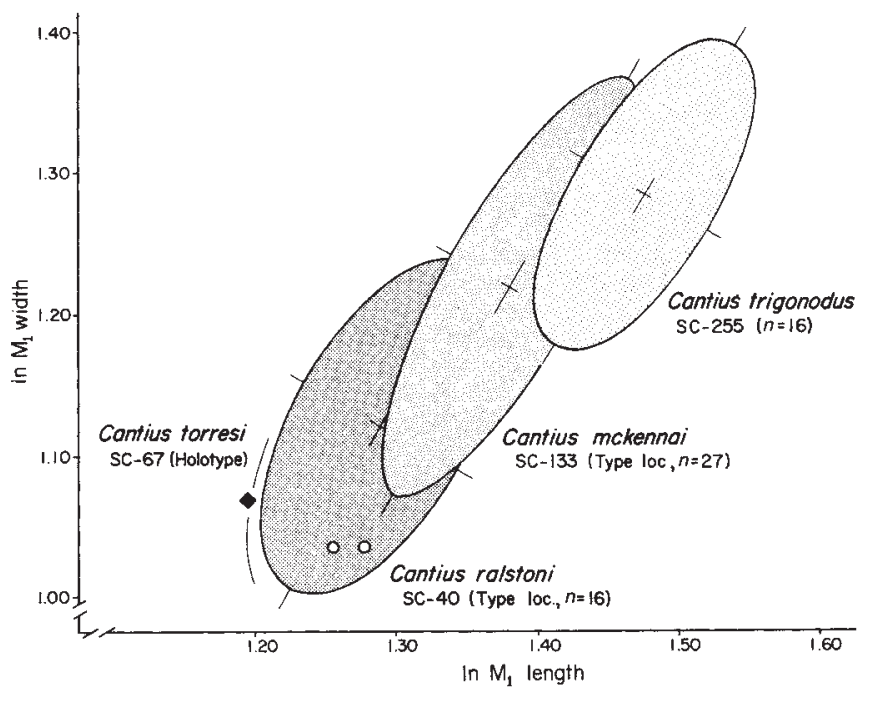

Fig. 2 Comparison of the sizes of the first lower molars in four species of Cantius from successive stratigraphically superposed intervals of the early and middle Wasatchian, Clark's Fork Basin, Wyoming. Equiprobability ellipses enclose $90 \%$ of the observed variation in early Wasatchian C. ralstoni (type sample), C. mckennai (type sample), and the later $C$. trigonodus. The holotype of $C$. torresi is just outside the $95 \%$ equiprobability contour for C. ralstoni. Open circles within the distribution of C. ralstoni represent the type sample of $C$. eppsi from Abbey Wood, Kent. Note that $C$. torresi differs from $C$. ralstoni and $C$. eppsi in shape as well as size, having a shorter and relatively broader $M_{1}$.

into a full postprotocingulum (later Cantius, Pelycodus). There is a complete lingual cingulum on $\mathbf{M}^{2} . \mathrm{M}^{1}$ is $3.3 \mathrm{~mm}$ long and $4.5 \mathrm{~mm}$ in maximum breadth. $\mathrm{M}^{2}$ is $3.3 \mathrm{~mm}$ long and $5.3 \mathrm{~mm}$ in maximum breadth. The crown of $\mathbf{M}^{3}$ is shorter and consequently relatively broader than those of $\mathrm{M}^{1}$ and $\mathrm{M}^{2}$; it is $2.5 \mathrm{~mm}$ long and $4.3 \mathrm{~mm}$ in maximum breadth.

Judging from the available evidence, $C$. torresi is the smallest and most generalized species of Cantius known anywhere. It is similar in size to $C$. eppsi from the Sparnacian Blackheath Beds of the United Kingdom (Abbey Wood, Kent), with a body weight estimated ${ }^{23}$ from tooth size to be $1,100-1,200 \mathrm{~g}$. C. torresi differs from $C$. eppsi in having shorter and broader premolars (Fig. $1 a, b$ ) and molars (Fig. 2). The type sample of $C$. torresi comes from the Clark's Fork Basin of northwestern Wyoming where more than 760 specimens of Cantius, including the type sample of $C$. ralstoni and the type sample of Cantius mckennai, are linked in one evolving lineage. As the oldest member of this lineage, $C$. torresi effectively defines the morphology of primitive North American Cantius.

Comparing the European C. eppsi from the type locality, Abbey Wood, with the North American sequence of Cantius species in the Clark's Fork Basin, the size and proportions of upper and lower cheek teeth agree most closely with $C$. ralstoni (Fig. 2), which suggests that $C$. eppsi and $C$. ralstoni represent equivalent grades of evolution and, further, that $C$. eppsi and C. ralstoni may be approximately equivalent in age. Radiometric dating and correlation based on palaeomagnetic stratigraphy are insufficiently precise to resolve time on this scale, but comparison of the fauna from SC-67, the type locality of C. torresi, with that from Abbey Wood substantiates an older age for C. torresi. Perissodactyls are particularly useful here, Hyracotherium from SC-67 being smaller and notably less lophodont than any European specimens (including problematical remains from the French locality of Meudon).

Donrussellia provincalis, a European contemporary of C. eppsi $i^{1,12}$, differs from $C$. torresi in being smaller and having the anteroposteriorly elongated $\mathrm{P}_{4}$ characteristic of Protoadapis and later Adapidae, but it could be derived from a generalized C. torresi or a similar structural ancestor. $C$. torresi has relatively square upper molars like those of the later North American Pelycodus jarrovii ${ }^{18,24}$ and, if intermediates were known connecting them through time, $C$. torresi could easily be regarded as an early species of Pelycodus.

Of greater interest and importance is the fact that the form of $\mathrm{P}_{4}$ in $C$. torresi is as similar to the fourth premolars of early tarsiiform Omomyidae as it is to those of later lemuriform Adapidae, suggesting that Omomyidae and Adapidae (and the prosimian infra-orders that they represent) were probably still little differentiated at the beginning of the Eocene. This premolar conformation linking Omomyidae and Adapidae serves, at the same time, to distinguish them from all archaic Palaeocene pleisiadapiform primates of more primitive 'praesimian' grade $^{25}$. Similarly, the presence of a limited Nannopithex fold, rather than a full postprotocingulum connecting the protocone to the posterior cingulum, is another feature distinguishing primitive Adapidae and Omomyidae from earlier plesiadapiform primates with a fully developed postprotocingulum. This weakens earlier dental evidence suggesting close linkage of Plesiadapis and its allies in the order Primates ${ }^{26}$. While I would still classify Plesiadapis as a primate ${ }^{27}$, new evidence and interpretations presented here and elsewhere ${ }^{11,16,25,27,28}$ indicate that Plesiadapiformes represent an evolutionary radiation distinct from primates of modern aspect.

Previous comparisons of European Sparnacian mammalian faunas with known North American early Wasatchian faunas indicated that $C$. eppsi and contemporary European mammals of other orders were more primitive and therefore probably older than $C$. ralstoni and its North American contemporaries $^{12,29}$, suggesting that primates of modern aspect, Artiodactyla, hyaenodontid Credonta, Perissodactyla and other Wasatchian groups reached North America by dispersal from Europe. The discovery of a new and distinctive mammalian assemblage at the base of the North American Wasatchian, including a primate $C$. torresi that is more primitive than any known European adapid, complicates this interpretation. Based on present evidence, it seems that Sparnacian primates of modern aspect and at least some representatives of other modern mammalian orders reached Europe by dispersal through North America.

The geographic area of origin of primates of modern aspect is as yet unknown, but the presence of Lemuroidea on Madagascar today, Lorisoidea in Africa since the early Miocene ${ }^{30}$, a possible Oligocene adapid (Oligopithecus) in Africa ${ }^{31}$, and the recent discovery of Oligocene Tarsioidea in Africa ${ }^{32}$ make it likely that primates of prosimian grade originated on the African continent. Africa and Europe were separated by the Tethys Sea and Obik Sea throughout the Palaeocene and most of the Eocene $^{33}$. However, Africa may have been connected to central Asia by way of the Arabian peninsula and Indo-Pakistan subcontinent ${ }^{34}$. Climatic warming in the late Palaeocene and earliest Eocene $^{21}$ undoubtedly facilitated poleward dispersal of endemic equatorial African mammals. Thus, one may reasonably speculate that the earliest primates of modern aspect evolved in equatorial Africa during the late Palaeocene and dispersed rapidly through Arabia, South Asia, Central Asia and North America to reach Europe as part of a broader pattern of faunal interchange on northern continents leading to the holarctic cosmopolitanism evident in the early Eocene.

I thank T. M. Bown and R. D. Martin for reviewing the manuscript, and J. J. Hooker for casts and discussion. Specimens were prepared by W. Ryan, figures by $\mathrm{K}$. Klitz. This research was supported by NSF grants BNS 80-16742, DEB 82-06242 and EAR 84-08647.

Received 10 May; accepted 1 November 1985

1. Godinot, M. C. r. hebd. Séanc, Acad. Sci, Paris D286, 1869-1872 (1978),

2. Hooker, J. J. \& Insole, A. N. Tertiary Res., Rotterdam 3, 31-45 (1980).

3. Dashzeveg, D. \& McKenna, M. C. Acta paldeont. pol. 22, 119-137 (1977). 
4. Dashzeveg, D. Bull. Soc. géol. Fr. Sér. 7 24, 275-281 (1982).

5. Rose, K. D. Science 208, 744-746 (1980).

6. Berggren, W. A., McKenna, M. C., Hardenbol, J. \& Obradovich, J. D. J. Geol. 86, 67-81 (1978)

7. Harland, W. B. et al A Geologic Time Scale (Cambridge University Press, 1982).

8. Simons, E. L. Bull. Br. Must. nat. Hist., Geol. 7, 1-36 (1962).

9. Russell, D. E., Louis, P. \& Savage, D. E. Univ. Calif. Publs geol. Sci. 73, 1-46 (1967).

10. Szalay, F. S. Folia Primatol 22, 116-133 (1974).

11. Gingerich, P. D. Folia Primatol. 28, 60-80; 144-153 (1977); J. hum. Evol, 10, 345-374 (1981).

12. Godinot, M. Palaeovertebrata 10, 43-126 (1981); Geobios, Mém. Spéc. 6, 403-412 (1982).

13. Rose, K. D. \& Krause, D. W. J. Mammal. 65, $721-726$ (1984).

14. Russell, D. E. \& Gingerich, P. D. C. r. hebd. Séanc. Acad. Sci, Paris D291, 621-624 (1980).

15. Bown, T. M. Folia Primatol. 25, 62-72 (1976).

16. Szalay, F. S. Bull. Am. Mus. nat. Hist. 156, 157-450 (1976).

17. Gingerich, P. D. \& Simons, E. L Contr. Mus. Paleont Univ. Mich. 22, 245-279 (1977).

18. Gingerich, P. D. \& Haskin, R. A. Contr. Mus. Paleont. Univ. Mich. 25, 327-337 (1981)

19. Rose, K. D. \& Bown, T. M. Nature 309, 250-252 (1984).

20. Bown, T. M. \& Rose, K. D. Folia Primatol. 43, 97-112 (1984)

21. Buchardt, B. Nature 275, 121-123 (1978).

22. Kraus, M. J. in Early Cenozoic Paleontology and Stratigraphy of the Bighom Basin, Wyoming (ed. Gingerich, P. D.) 87-94 (University of Michigan Museum of Paleontology, Ann Arbor, 1980).

23. Gingerich, P. D., Smith, B. H. \& Rosenberg, K. Am. J. phys. Anthrop. 58, 81-100 (1982)

24. Rose, K. D. \& Bown, T. M. J. Paleont. 58, 1532-1535 (1984).

24. Rose, K. D. \& Bown, T. M. J. Paleoni. 58, 1532-1535
25. Gingerich, P. D. Yb. phys. Anthrop. 27, 57-72 (1984).

26. Gingerich, P. D. in Prosimian Biology (eds Martin, R. D., Doyle, G. A. \& Walker, A. C.) 531-541 (Duckworth, London, 1980).

27. Gingerich, P. D. in Major Topics in Primate and Human Evolution (eds Wood, B. A., Martin, L. B. \& Andrews, P.) (Cambridge University Press, in the press).

28. MacPhee, R. D. E., Cartmill, M. \& Gingerich, P. D. Nature 301, 509-511 (1983).

29. Gingerich, P. D. A. Rev. Earth planet. Sci. 8, 407-424 (1980).

30. Walker, A. C. in Prosimian Biology (eds Martin, R. D., Doyle, G. A. \& Walker, A. C.) 435-447 (Duckworth, London, 1980).

31. Gingerich, P. D. Geobios, Mém. Spéc. 1, 165-182 (1977)

32. Simons, E. L. \& Bown, T. M. Nature 313, 475-477 (1984)

33. McKenna, M. C. Ann. M. bot. Gdn 62, 335-353 (1975).

34. Smith, A. G. \& Briden, J. C. Mesozoic and Cenozoic Paleocontinental Maps (Cambridge University Press, 1977).

\section{Reconstruction of African human diet using bone collagen carbon and nitrogen isotope ratios}

\section{Stanley H. Ambrose* \& Michael J. DeNiro†}

Department of Earth and Space Sciences, and †Archaeology Program, University of California, Los Angeles, California 90024, USA

Behavioural modifications associated with the exploitation of new food resources have been linked to major steps in hominid evolution and in subsequent human cultural development ${ }^{1,2}$. Testing of specific hypotheses concerning the influence of dietary change on these processes would be facilitated by quantitative estimates of early hominid and human diets. Although most methods of obtaining such evidence provide only qualitative information ${ }^{2}$, the stable carbon and nitrogen isotope ratios of animal tissues, and in particular, bone collagen, can be used to quantify the consumption of foods having different isotopic compositions ${ }^{3-5}$. As reported here, analysis of the collagen of historic and prehistoric African human populations from Kenya, Tanzania and South Africa that have reasonably well-known diets shows that stable carbon and nitrogen isotope ratios in bone collagen can distinguish marine foragers from populations consuming terrestrial resources, pastoralists from farmers, farmers consuming grains from those consuming non-grain crops, and camel pastoralists from capri-bovine pastoralists.

Several major classes of food resources can be distinguished on the basis of their isotopic composition. Among terrestrial plants, carbon isotope ratios differentiate between $C_{3}$ plants and $\mathrm{C}_{4}$ and CAM (crassulacean acid metabolism) plants ${ }^{6} . \mathrm{C}_{4}$ plants include maize, sorghum, African millets and tropical pasture grasses. Most succulents such as cacti are CAM plants. Other staple foods, including wheat, rice, nuts and most vegetables and fruits, are $\mathrm{C}_{3}$ plants ${ }^{6}$. The average $\delta^{13} \mathrm{C}$ values (see Table

* Present address: Department of Anthropology, University of Illinois, Urbana, Illinois 61801, USA.

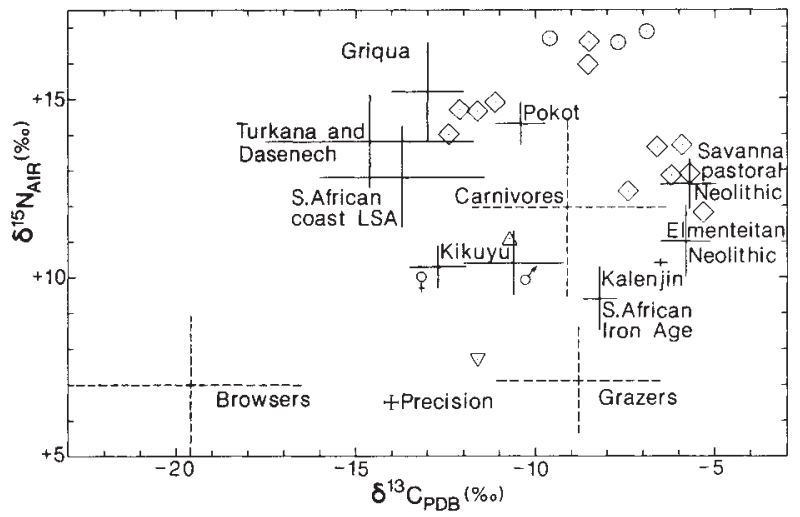

Fig. $1 \delta^{15} \mathrm{~N}$ and $\delta^{13} \mathrm{C}$ values of bone collagen from African human and non-human mammal populations and individuals. The means ( \pm 1 s.d.) are indicated by symbols or solid lines for human groups and by broken lines for modern non-human East African mammals. The symbols represent individual determinations for the following human groups and individuals: $\triangle$, proto-historic Kikuyu from site GsJj31, Naivasha, Kenya; $\nabla$, proto-historic Luyia from site GnJc51, Bungoma, Kenya; $\odot$ and $\odot$, prehistoric individuals from Sechikuencho Cairns and from Gishimangeda Cave respectively, Lake Eyasi, northern Tanzania.

1 for an explanation of $\delta$ values) for $\mathrm{C}_{3}, \mathrm{C}_{4}$ and CAM, and marine plants, are $-26.5,-12.0$, and $-19.0 \%$, respectively ${ }^{6}$. Nitrogen isotope ratios distinguish marine from terrestrial plants and nitrogen-fixers from other plants. The $\delta^{15} \mathrm{~N}$ values of marine plants are $\sim 4 \%$ higher than those of terrestrial plants that use soil nitrogen ${ }^{5}$. Plants that use fixed atmospheric nitrogen (for example, legumes) have lower $\delta^{15} \mathrm{~N}$ values than other plants? The isotopic compositions of animal tissues reflect the isotope ratios of the plants at the bases of food chains ${ }^{3,4}$. However, there is a small stepwise enrichment of ${ }^{13} \mathrm{C}$ and a larger one of ${ }^{15} \mathrm{~N}$ as carbon and nitrogen move to higher trophic levels ${ }^{3-5}$. In fact, enrichment in ${ }^{15} \mathrm{~N}$ is large enough to serve as an indicator of trophic level ${ }^{5}$.

Given these basic differences in the isotopic composition of food resources, it should be possible to use $\delta^{13} \mathrm{C}$ and $\delta^{15} \mathrm{~N}$ values to distinguish between human populations relying mainly on animal products as opposed to plant foods, the meat of grazing animals as opposed to that of browsing animals, or $\mathrm{C}_{3}$ as opposed to $\mathrm{C}_{4}$ plants. These expectations are fulfilled for modern non-human mammals collected in Kenya and Tanzania ${ }^{8}$ (see Fig. 1). These results, based on the analysis of 15 carnivores, 111 grazers and 82 browsers $(10,13$ and 18 species, respectively) serve as a standard against which isotopic data for humans presented in this study can be evaluated.

Bones of historic, proto-historic (Table 1) and prehistoric (Table 2) humans were obtained from museum collections in Kenya, Tanzania and South Africa. Bone collagen was purified and its $\delta^{13} \mathrm{C}$ and $\delta^{15} \mathrm{~N}$ values determined by mass spectrometry, as described elsewhere ${ }^{3-5}$.

Table 1 lists, in rank order of importance, the major components of the diets of Kikuyu farmers of central Kenya ${ }^{9}$, Luyia farmers of western Kenya ${ }^{10}$, Turkana and Dasenech pastoralists of northern Kenya ${ }^{11,12}$, highland and lowland Pokot of northwest Kenya ${ }^{13,14}$, Nandi and Kipsigis (Kalenjin) farmers and pastoralists of highland western Kenya ${ }^{13}$, and Griqua pastoralists and farmers of the Orange Free State, South Africa ${ }^{15}$.

The diets of the prehistoric populations are less well understood because of food preservation biases inherent in the archaeological record. The diet of Elmenteitan Neolithic and Iron Age peoples of highland western Kenya is considered to have been similar to that of the historic Kalenjin ${ }^{16}$. The diet of Savanna Pastoral Neolithic (SPN) peoples appears to have been dominated by cattle and caprine pastoralism but their degree of dependence on agriculture is under debate ${ }^{16,17}$. There is inadequate information regarding the diets, ages and cultural 